\title{
Reading culture development with optimizing digital library services during the pandemic
}

\author{
A. Asari*, I.A. Zakaria, A. Prasetyawan, M. Safii, T. Kurniawan, L.A. Rahmania \& C. Fajar \\ Universitas Negeri Malang, Malang, Indonesia
}

\begin{abstract}
ABSTRACT: This study aims to analyze the quality of the implementation of a digital library based on the Senayan library management system (SLiMS) application system to increase student reading interest in the MI Nurul Islam Bululawang Malang school library, starting from the quality of the system and constraints in the implementation process. The subject of this research is the librarian of the MI Nurul Islam school library, and the object of this research is the SLiMS application system. This research uses descriptive research with a qualitative approach. From the results of this study, it can be concluded that the MI Nurul Islam school library, in implementing digital libraries to support the development of student reading interest, has constraints on human resources, information and communication technology infrastructure in the implementation process of SLiMS-based digital libraries.
\end{abstract}

Keywords: reading, digital library, school library

\section{INTRODUCTION}

The digital library system is a library management process using information technology (IT) (Wenige \& Ruhland 2018). The use of information technology in libraries aims to improve work efficiency and service quality to users (the right information, the right users, at the right time), related to the role and function of libraries as a force in the preservation and dissemination of scientific and cultural information that develops in line with human needs (Ahmad \& Abawajy 2014). As the preservers of knowledge, the school library carries out activities which include hunting, collecting, identifying, managing, and disseminating information to the general public, which in its development can be assisted by communication and information technology equipment (Purwono 2008).

Libraries are institutions that manage collections of written works, printed works and/or recorded works professionally with a standard system to meet the needs of education, research, preservation, information and recreation for visitors (Basuki 2004). Library collections contain all information in the forms of written works, printed works and/or recorded works in various media forms that have educational value, which are collected, processed and served (Basuki 2020). Libraries have a function as a vehicle for education, research, conservation, information, and recreation to increase the intelligence and empowerment of the nation. The library aims to provide services to readers, foster a love of reading and broaden horizons and knowledge to educate the nation's people (Suwarno 2010). In Law No.43 of the year 2007 concerning libraries, article 12 paragraph (1) explains that library collections are selected, processed, stored, served, and developed by the interests of users by paying attention to developments in information and communication technology. Each library develops library services through advances in information and communication technology (Bafadal 2009).

Many libraries are constrained in carrying out the provisions of the above laws and regulations. Based on conditions in the field, the obstacles that arise are related to the infrastructure that supports

*Corresponding author: andi.asari.fs@um.ac.id 
the library (Kusmayadi,2006). The availability of computers and library software is of course the main requirement in seeking the implementation of information technology in libraries (Jogiyanto 2007). Regarding the implementation of information technology in school libraries, in the present era, efforts have certainly been made (Kang \& Jung 2018). However, for the implementation of automation systems and digital library systems, not all school libraries have implemented them (Gupta 2019). This is of course a common concern, to realize the implementation of information and communication technology in school library services (Pendit 2008).

However, not all libraries have implemented automation systems optimally. This is caused by several things. First, the constraints in determining the applications of a library automation system (Boyles \& Meisinger 2020). Second, the ability to create personnel or human resources who have not received much training in the field of library automation systems (DeLone \& McLean 2003). The library here is the MI Nurul Islam school library. Seeing the role of digital libraries in supporting the school library management process, it can be concluded that the SLiMS has an important role (Aswari et al. 2020). However, in practice, it is not necessarily a SLiMS that has the best quality and SLiMS does not always have a positive impact on the school library. Therefore, to find out the quality of the system SLiMS in the MI Nurul Islam school library needs to be examined and tested for the quality of its system (Petter 2008).

\section{METHODS}

This research used a qualitative approach. The data in this study was in the form of interviews with librarians and librarians in terms of system quality, information quality and service quality. The data sources that researchers used in this study were obtained from informants and documents. At this stage the researcher carried out the data collection process using the active participant method, namely the researcher collected data by being directly involved in the object to be studied. The data collection techniques used in this study were observation, interviews and document study. The data sources in this study were obtained based on information about the implementation of the digital library in the MI Nurul Islam school library. The main data sources are library students, teachers and librarians for a total of eight people from a total of 50 visitors. These eight people were chosen because they have accessed the digital library system (Mukhtar 2013).

\section{RESULTS AND DISCUSSION}

\subsection{Quality of library automation systems in support of reading culture}

In this study, the quality of the SLiMS is measured based on criteria according to Hamilton in Jogiyanto (2007). There are eight indicators, (a) a proposed data currency: in this study, the capabilities of the SLiMS information system in displaying library data or information can always be updated properly; (b) response time: in this study the SLiMS was used to process work performed by system users, in this case, the library work done by librarians was fast enough. The SLiMS has a fast response time in processing commands from system users or system operators; (c) replacement time is the speed of the SLiMS, in this study the SLiMS has a fairly fast feature change time, such as changing menus that have a fairly fast processes; (d) data accuracy, in this study the accuracy of the information or data displayed by the SLiMS is determined by the system user. The SLiMS has a fairly high level of data accuracy in displaying data or information; (e) reliability, in this study, it was found that the SLiMS can be relied upon in the process of completing tasks or work in MI school libraries Nurul Islam. SLiMS can be used in library management from collection management to collection services; (f) completeness, in this study it was found that the SLiMS has quite complete features in supporting the management of the MI Nurul school library and the completeness of the menu features that exist in the SLiMS strongly supports the management and service processes for users of the MI Nurul Islam school library; (g) the flexibility: flexibility 
means the SLiMS can be applied to the MI Nurul Islam library and its unique conditions, such as the condition that the library has a limited number of librarians, so using the SLiMS can take some pressure off library staff. In terms of system access, the SLiMS can be accessed using ethernet and internet-based computer networks. Finally, (h) ease of use: in terms of ease of use the SLiMS is quite easy to understand. In this study, it can be concluded that the operation of the SLiMS is quite easy and it can be used by librarians and librarians without training.

\subsection{Quality of information to support reading culture}

The quality of the information is part of the indicators to be measured. The quality of the information in question is the quality of information issued or produced by the SLiMS. In this study, the quality of information is measured by Mukhtar's (1999) opinion that information must be reliable, relevant, timely, complete and understandable. A complete explanation is as follows. It must be, (a) reliable: from the research results it can be found that the SLiMS in the MI Nurul Islam library has timely quality information when needed by the user. So the information released by the SLiMS is reliable. It must be, (b) relevant: in the process of searching for information on the SLiMS, it must displayed information that is relevant to users. From the results of the study, it can be concluded that the SLiMS always displays the information desired by system users, and the information released by the SLiMS is suitable and appropriate to user requests in the MI Nurul Islam library. It must be, (c) timely: the SLiMS is punctual and accurate. From the research results, it can be concluded that the SLiMS can present information on time according to the needs of system users. It must be, (d) complete: the completeness of the information displayed by the SLiMS is quite complete. From the research results, it can be concluded that the SLiMS, when displaying information, is complete according to the user's wishes. It must be, (e) understandable: in terms of convenience, it can be concluded that the SLiMS has information that is easy to understand by users.

\subsection{Quality of service in supporting a reading culture}

The quality of service in this case is the quality of service that can be provided by the SLiMS to system users. This study refers to the opinion of Jogiyanto (2007). That there are five indicators used to measure the quality of services in the SLiMS. These indicators include, (1) reliability: reliability in this case is the user's perception of the reliability of the SLiMS. From the research results, it can be concluded that the SLiMS can be relied upon in completing the work and tasks of managing the MI Nurul Islam library. The next indicator is (2) responsiveness, responsiveness in this case is the user's perception of the responsiveness obtained by the user in completing tasks using the SLiMS. From the results of the study, it can be concluded that librarians using the SLiMS have a high enough responsiveness to immediately complete work by utilizing services in the SLiMS. (3) is assurance, in this case, the guarantee is the user's perception of ease when using the SLiMS. From the research results, it was found that librarians using the SLiMS can be helped and the librarian's work becomes easier to complete. (4) is empathy, empathy here is the system user's perception of the suitability of features or menus in the SLiMS. From the research results, it can be concluded that the features or menus in the SLiMS are quite complete following the expectations and desires of system users. The next indicator is (5) tangibles, in this case, tangibles are the physical components of the implementation of the SLiMS in the MI Nurul Islam library. Physical components here includes two aspects, namely computer equipment and computer networks. From the research results, it was found that the implementation of the SLiMS in the MI Nurul Islam library was supported by computers that were of moderate quality, and the number was still minimal, namely, there was only one computing device. Then, the network quality used by the MI Nurul Islam library is classified as not good because it still uses a wifi network that has a small capacity so that the speed is slow. This can be a problem in the process of implementing the SLiMS which has the effect of reducing the quality of MI Nurul Islam library services. Therefore, these two aspects need to be improved both in terms of quality and quantity, to support the performance and good service of the MI Nurul Islam library. 


\section{CONCLUSION}

Based on the results of research that has been done, it was found that the implementation and development of the SLiMS in the MI Nurul Islam library in terms of system quality is quite good because it can always display updated information so that it can foster reading interest, it has a fairly fast response time and feature change time, the information displayed is always accurate, has complete features, is easy to operate and can be accessed using ethernet and internet networks, making it easier for users to get information and have an impact on increasing user reading interest. Then, in terms of information quality, the SLiMS can provide accurate and complete information. However, the quality of the content shown by the SLiMS is still sometimes poor. Furthermore, in terms of service quality, the SLiMS can make work easier and more reliable in the MI Nurul Islam library; the features and menus in the SLiMS are helpful in supporting library management. The use of the SLiMS in the MI Nurul Islam library can make librarians more responsive in the process of completing work in the library. However, the implementation of the SLiMS in the MI Nurul Islam library is not supported by a good computer infrastructure and internet network. There is only one computer so it does not support user service processes and the existing internet is of poor quality.

\section{REFERENCES}

Ahmad, M., \&Abawajy, J. H. 2014. Digital library service quality assessment model. Procedia-social and behavioral sciences, 129: 571-580.

Aswari, M., Kristiawan, M., \&Fitria, H. 2020. Senayan Library Management System Application as Digital Library Management. International Journal of Progressive Sciences and Technologies, 20(2): 129-136.

Bafadal, Ibrahim, 2009, School Library Management. Jakarta: Earth Literacy.

Basuki, S. 2004. Perpustakaan Nasional dan Asosiasi Pustakawan di Indonesia dilihat dari Segi Sejarah. The National Library and the Indonesian Librarian Association: a historical overview, in Temu Ilmiah Berdirinya Perpustakaan Nasional RI dan Peran Organisasi Profesi.

Basuki, S. 2020. Pengertian Pustakawan Menurut Perundang-Undangan Indonesia Serta Berbagai Dampaknya. Media Pustakawan, 16(2): 52-57.

Boyles, J. L., \&Meisinger, J. 2020. Automation and Adaptation: Reshaping journalistic labor in the newsroom library. Convergence, 26(1): 178-192.

Delone, W. H., \& McLean, E. R. 2003. The DeLone and McLean model of information systems success: a ten-year update. Journal of management information systems, 19(4): 9-30.

Gupta, M. K. 2019. Library Automation: Issues, Challenges and Remedies. International Journal of TechnoManagement Research: 19-25.

Jogiyanto, 2007. Success Models of Information Technology Systems. Yogyakarta: Andi

Kang, B. S., \& Jung, Y. 2018. Awareness on the Establishing and Operation of the Makerspaces in School Libraries. Journal of the Korean Society for Library and Information Science, 52(3): 171-192.

Kusmayadi, Eka. 2006. Online Study Public Access Catalog (OPAC) in Library Services and Agricultural Technology Dissemination. Agricultural Library Journal, 15(2).

McGill, T., Hobbs, V., \& Klobas, J. 2003. User developed applications and information systems success: A test of DeLone and McLean's model. Information Resources Management Journal (IRMJ), 16(1): 24-45.

Mukhtar. 2013. Practical Methods of Qualitative Descriptive Research. Jakarta: Reference (GP Prees Group)

Pendit, P., 2008. Digital Libraries from A - Z. Jakarta

National Library of Indonesia. 2014. INLIS Lite User Manual Version 2.1.2 (Integrateg Library System). Jakarta.

Petter, Stacie., William H DeLone and Ephraim R. McLean. 2008. Measuring information systems success: models, dimensions, measures, and interrelationships. European Journal of Information Systems. 17: 236263.

Salmon, Stephen R. 1985. Library Automation Systems, Marcel Dekker, New York

Suwarno, Wiji. 2010. Library Science \& Librarian Code of Ethics. Yogyakarta: Ar-Ruzz Media.

Wenige, L., \& Ruhland, J. 2018. Retrieval by recommendation: using LOD technologies to improve digital library search. International Journal on Digital Libraries, 19(2-3), 253-269. 